\title{
The Larva of Nicothoë astaci and its Systematic Position.
}

By

\author{
Robert Gurney, D.Sc.
}

With 6 Figures in the Text.

Mr. Leigh-Sharpe, in his account of the external structure of this interesting Copepod (1926), concludes that it is most nearly related to the Ascomyzontidæ. Having recently obtained a number of larvæ, hatched from adults obtained at Plymouth, and finding that my own conclusion as to the relationship of the genus differs from that of Mr. Leigh-Sharpe, it seems worth while to describe the larvæ and the bearing they seem to have upon the systematic position of the adult.

The larvæ hatch and become active inside the egg-sac.* Immediately after becoming free they swim vigorously for a short time, but very soon sink to the bottom and remain quiescent, with occasional spasms of activity. This quiescence may, of course, not be normal; but, as the larvæ remained alive for over a week, their behaviour during the first days cannot be due to ill-health. One may suggest that this is the normal procedure; the early activity ensures some dispersal and the later rest on the bottom brings them into touch with a new host. I have seen exactly the same thing in the larvæ of Chondracanthus lophii. As hatching proceeded the beaker in which they were contained became filled with swimming nauplii; but the next morning all were on the bottom and there remained, apparently perfectly healthy, and readily stirred to sudden spurts of movement, for several days.

The larva hatches as a Cyclopid with two pairs of legs and a rudimentary third pair. (Fig. 1.)

Length : $\cdot 28 \mathrm{~mm}$.

The cephalothorax is as long as the rest of the body, and includes the somite of leg 1 . The somites of legs 2 and 3 are free, and are followed by two legless somites. Furcal rami short, bearing 6 setæ, 1 dorsal and 5 lateral and terminal. The innermost seta is the longest, and between it and the next one is a delicate sensory seta. No eye is visible.

The antennules are of 3 joints (Fig. 3), the third the longest and bearing numerous setæ. The antennæ are difficult to make out, but appear to

* This has already been noted by Rathke, 1843 . 
consist of four joints, the last two flexed upon the second (see Fig. 3). The last joint ends in a spine and bears an inner seta. The mandibles are enclosed within the mouth tube, which has the form of a sucker. The distal part of the sucker consists of a chitinous ring strengthened by radial thickenings. The ring is enclosed by a transparent membrane broken at its outer edge into a very delicate fringe. In the bottom of the conical hollow can be seen the mouth opening through which the tips of the mandibles protrude. While the distal disc is entire, except

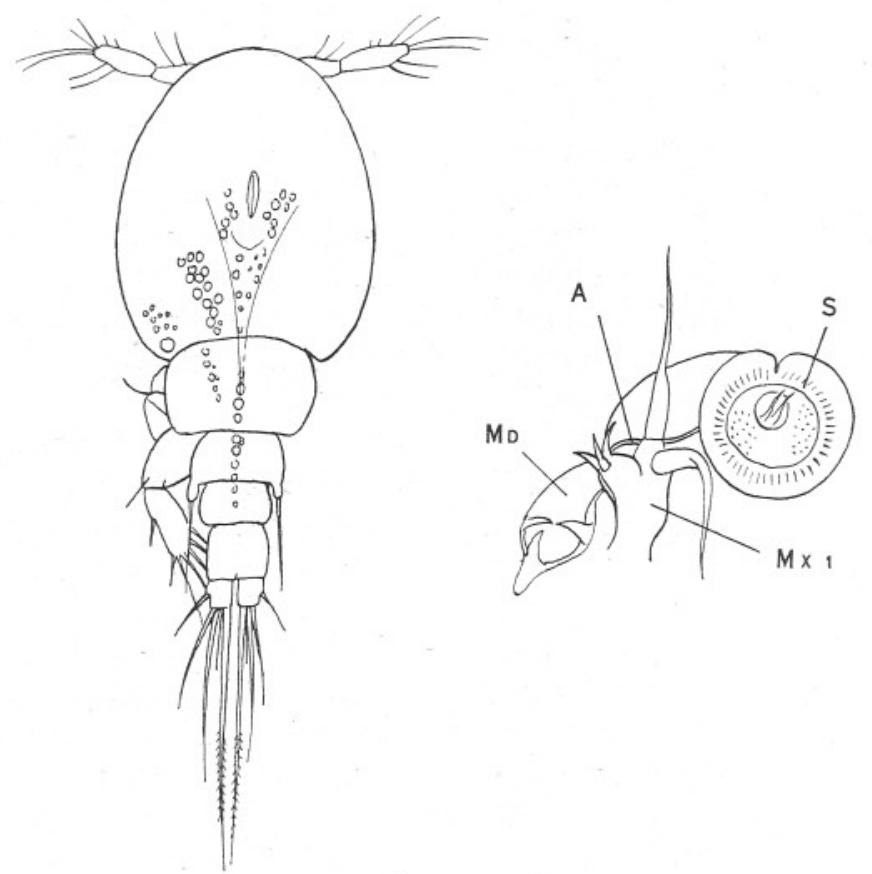

FIG. 1.-Copepodid larva, dorsal view.
Fra. 2.- Side view of sucker. S. sucker. A. lateral suture of sucker. Md. mandible. Mx. 1. Maxillule.

for an anterior median indentation, the mouth tube itself is made up of an anterior and a posterior part, representing the upper and lower lips, the division between them being marked by a distinct suture visible in side view (Fig. 2). The mandibles, which are hinged to the body close to, and outside, the base of the maxillules, pass into the mouth tube through a gap in the suture.

Close against the antennæ and just behind the sucker is the maxillule. This is made up of two parts. Quite distinct is a small papilla bearing three short spines, and on the inside of this is a cylindrical joint bearing two long flagella. 
The maxilla is a strong three-jointed appendage, situated some way behind the maxillule. The basal joint is very broad, and is followed by two simple narrow joints, the distal one with a brush of spines at the end.

The maxillipede is four-jointed, the last joint bearing a strong claw and a seta.

The two pairs of swimming legs are biramous, the branches one-jointed. The third pair is represented by a bilobed rudiment, the outer lobe being a small papilla, visible dorsally, bearing one long seta.

In the adult there is no essential difference in the arrangement and structure of the mouth parts (Fig. 4). The sucker seems to be rather more

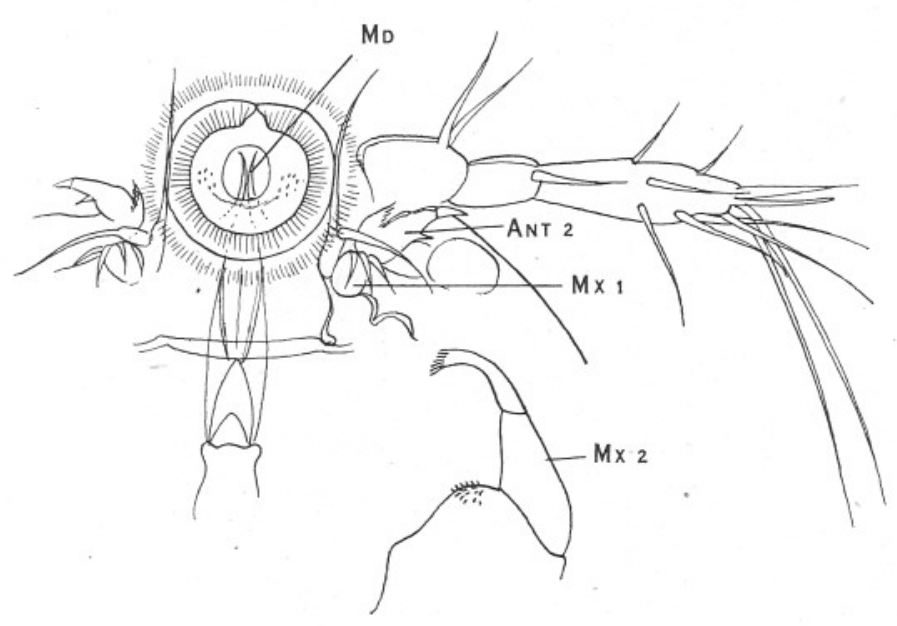

FIG. 3.-Copepodid. Ventral view of head region. Ant. 2. Antenna. Md. Mandible. Mx. 1. Maxillule. Mx. 2. Maxilla.

complicated, and on either side of the mouth, in the sucker-cone, is a pad covered with minute prickles.

The maxillule has much the same form, but there is now a third flagellum on the anterior branch of it (Fig. 6).

In Mr. Leigh-Sharpe's figure of the adult there are two structures shown which should be mentioned, namely, the second antenna and the pair of "lunules."

In a specimen cleaned with caustic potash both these structures can be seen and appear to be chitinous bodies enbedded in the carapace. The "lunules "show no resemblance to the lunules of Caligus to which he has compared them.

As regards the systematic position of Nicothoë, Mr. Leigh-Sharpe points out a number of Cyclopoid features and concludes that it is a 
member of the Ascomyzontidæ.* At the same time he gives as examples of Caligoid features the presence of "lunules," the suctorial mouth, and "a first attempt at the inauguration of a genital segment." I think the "lunules" can be dismissed, and the sucker-like mouth tube has much less resemblance to the mouth tube of Caligus than to that of some other Copepods.

It seems to me that the affinity is not with the Caligidæ nor with the Ascomyzontidæ, but with the Choniostomatidæ.

If a comparison is made between the larva of Nicothoë and that of a

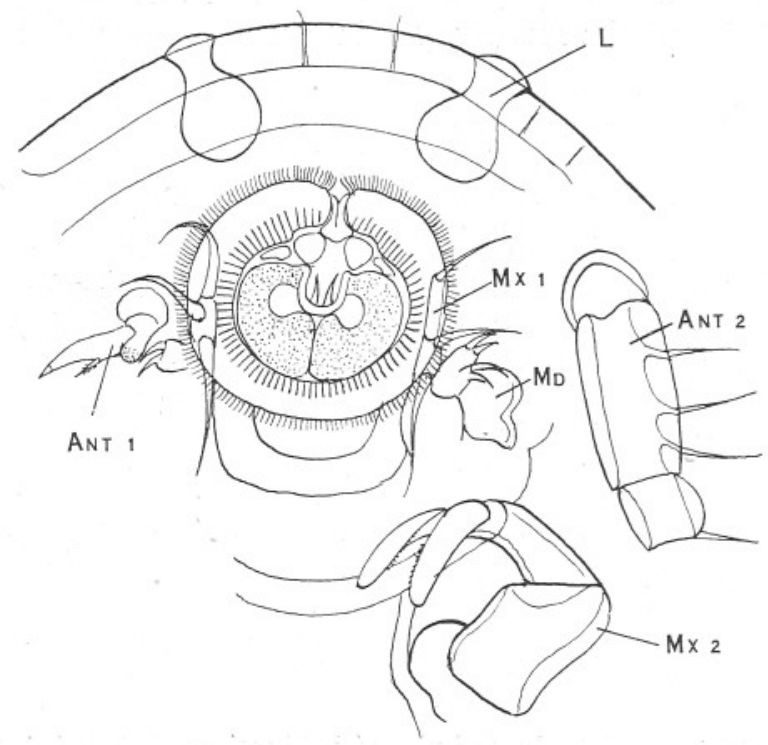

FIG. 4.-Adult female, ventral view of head region. L. so-called Lunule.

Choniostomatid-e.g. Stenothocheres (Hansen, 1897, pl. 1. fig. 1, 1) the agreement is almost startling. Apart from the general Cyclopoid form which in itself means little at this stage, we have a similar three-jointed antennule; the same form of mouth tube, with the same sucker; the same form of maxillule, and almost identical maxilla and maxillipede. In both cases there are two pairs of functional legs and a rudiment of leg 3 , and the arrangement of setæ on the furcal rami is the same. The detailed structure of the maxillule in the Choniostomatidæ is not very clearly described or

* Leigh-Sharpe (1926, p. 153): "I consider it preferable to associate Nicothoë with the genera Pœcilopes and Lophiropes (with which, however, I am not yet acquainted) in the family Ascomyzontidæ (Asterocheridæ)." Compare Audouin and Milne Edwards (1826, p. 351): "Il n'est pas moins certain qu'il doit être rangé dans l'ordre des Branchiopodes de M. Latreille; mais il devient assez difficile de lui assigner une place plutôt dans la section des Pœcilopes que dans celle des Lophiropes." 
figured by Hansen, but it seems to be built on the same plan and to include two or three flagella as in Nicothoë. The styliform mandible in both cases enters the base of the mouth tube and projects through the small mouth opening.

A further point of agreement is that in both larvæ there is a projecting median ventral ridge just in front of leg 1 . This is very much more prominent in the Choniostomatidæ, and is named the "pouch" by Hansen.*

It may be no more than a coincidence that Nicothoë is parasitic in the gill chamber of a Decapod, and that all Choniostomatidæ are parasitic on

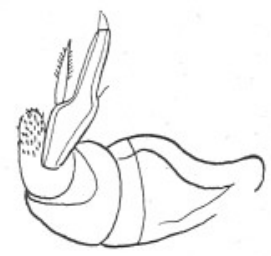

FIG. 5.-Antenna of

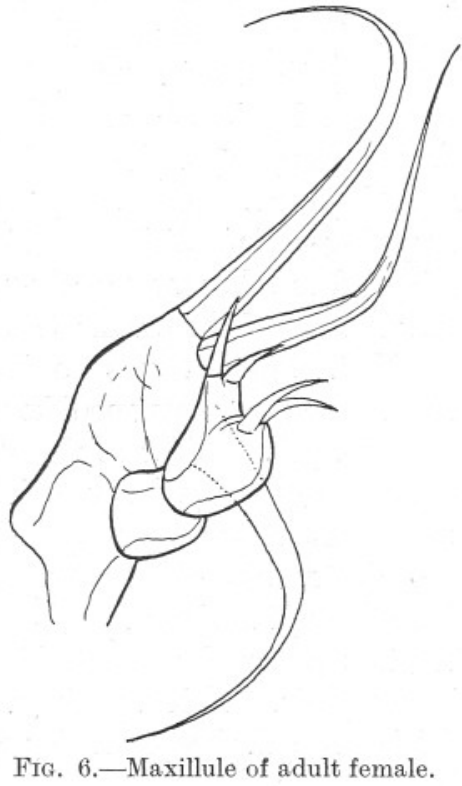
adult female.

various Crustacea, including some also in the gill chamber of Decapods; but it is a fact which should at least be thrown into the scale with the other resemblances.

In the Choniostomatidæ the copepodid larva becomes fixed to a host and moults directly into the degenerate form of the adult. We do not know the course of development in Nicothoë, but there is little degeneration in the adult, which has the full number of normal posterior appendages and the full number of abdominal somites. In the Choniostomatidæ not more than two pairs of legs are developed, and there is rarely in the adult any definite abdominal region. The antennules are of three joints,

* A similar, very prominent, ridge is found in the larval form known as "Saphirella," which probably belongs to the Clausidiidæ. 
the second shortest and the third longest, exactly as in the larva of Nicothoë.

I suggest that Nicothoë represents more or less closely the primitive Choniostomatid form, and that the Choniostomatidæ themselves are really pædogenetic larval forms.

There is a striking tendency among the semi-parasitic and parasitic Crustacea to abbreviation of development, to which attention has already been directed by Canu (1892, p. 91). There may be only one or two nauplius stages, and the larva may seek a host in the first Copepodid stage (Lernæa) or the second (Ascidicolidæ).

Such early attachment to a host, before the development of the full complement of legs, seems to provide a condition most favourable to the occurrence of pædogenesis. There is, one might say, no inducement for the larva to develop legs or an abdomen which will never be of any use, and every advantage in the attainment of sexual maturity without further development. Garstang (1928) has interpreted the Appendicularians as pædogenetic Doliolids, and it is possible that this interpretation may be applied to other apparently " degenerate " animals.

The relationship of the Choniostomatidæ to other groups is a question still undecided. Hansen goes no further than to say that they come " much nearer to the Lernæopodidæ than to any other form of parasitic Copepoda" (p. 86). So far as the structure of the adult is concerned, there seems to be more affinity with the Ergasilidæ and Clausiidæ, but there is no doubt that there are points of resemblance between the larvæ of the Choniostomatidæ and those of the Lernæopodidæ and the Lernæidæ (and through the latter to the Caligidæ). Any real decision on this point involves a complete reconsideration of the parasitic and semiparasitic Copepods. Such a revision must take into account above all the larval forms, and the possibility of pædogenesis must also be borne in mind.

\section{LITERATURE.}

1826. Audoutn, V., and Mirne Edwards. Mémoire sur la Nicothoë, animal singulier qui suce le sang des Homards. Ann. Sci. Nat., Paris, IX, pp. 345-359.

1850. Beneden, P.-J. van. Mémoire sur le Développement et l'organisation des Nicothoés. Nouv. Mém. Acad., Bruxelles, XXIV.

1892. CAnU, E. Les Copépodes du Boulonnais. Trav. Lab. Zool., Wimereux, VI.

1928. Garstang, W. The morphology of the Tunicata and its bearing on the Phylogeny of the Chordata. Quart. Journ. Mic. Sci., LXXII, p. 93. 
1897. Hansen, H. J. The Choniostomatidæ, a family of Copepoda, parasites on Crustacea Malacostraca. Copenhagen.

1926. Leigh-Sharpe, W. H. Nicothoë astaci (Copepoda), with a revision of the appendages. Parasitology, XVIII, pp. 148-153.

1843. Rathke, H. Beiträge zur Fauna Norwegens. Crustacea. Nov. Act. Acad., Leopold. Carol. XX, p. 102. (Description of Nicothoë and figures of larva.) 
